\title{
O escravo e o asno: o herói não idealizado no romance grego antigo ${ }^{1}$
}

\begin{abstract}
Adriane da Silva Duarte ${ }^{2}$
Resumo: Esse artigo pretende delimitar um componente popular nas narrativas romanescas da Antiguidade grega a partir da constituição de um herói não idealizado e que tem origens ou frequenta os estratos mais baixos da sociedade. A aproximação a esse universo se dará através do exame do lugar que esses personagens ocupam na escala social, em vista, sobretudo, da exploração da força de trabalho, estendendo-se a análise a semelhanças estruturais entre as Romance de Esopo e Lúcio ou o asno, do Pseudo-Luciano.

Palavras-chave: Romance grego antigo; Romance de Esopo; Lúcio ou o asno.

Abstract: This paper focuses on pointing a popular component of the Ancient Greek Novel, i.e., the making up of a non-idealized hero originated in, or frequently associated to the lowest strata of society. The approach to this universe will be carried through the examination of the place occupied by these characters in the social scale, keeping in view, above all, the workforce exploitation they are subjected to in Aesop Romance and Pseudo Lucian's The Onos, analysing the structural similarities of both texts.

Keywords: Ancient Greek novel; Aesop Romance; The Onos.
\end{abstract}

Introdução: o mundo do trabalho no romance grego antigo

Sob a denominação romance grego antigo agregam-se diversas obras narrativas compostas majoritariamente em prosa, de natureza ficcional, durante o período imperial da Antiguidade (I a V d.C.). Nesse conjunto, costuma-se distinguir os romances de amor idealizados, protagonizados por jovens da elite grega, caracterizados pela beleza física e nobreza de caráter, cuja paixão recíproca deve ser testada; e os de vertente cômico-realista, centrados nas peripécias de um personagem de certa forma marginal e cheio de expedientes. A este herói vou dedicar minha atenção, buscando estabelecer um paralelo entre Esopo e Lúcio, protagonistas respectivamente de Romance de Esopo (RE) e Lúcio ou o asno $(\operatorname{LoA}) .^{3}$

1 Esse texto integra a pesquisa $O$ romance grego como literatura popular, desenvolvida com o apoio do CNPq (Bolsa de Produtividade em pesquisa, 303363/2018-5).

2 Doutora em Letras pela Universidade de São Paulo (USP). Professora associada da USP na área de língua e literatura grega. Desenvolve o projeto de pesquisa "O romance grego como literatura popular", com apoio do CNPq.

3 Lúcio ou o asno é um texto polêmico, tanto no que concerne sua autoria, quanto no que respeita a sua forma. Fócio (Biblioteca, 129) menciona dois livros com a mesma história, um atribuído a Luciano, Lúcio ou o asno, e outro, intitulado Metamorfoses, a Lúcio de Patras. A existência desse último é contestada, uma vez que o nome de seu suposto autor, do qual não há outra notícia, é coincidente com o do narrador do romance, 
Meu interesse reside na tentativa de delimitar um componente popular nas narrativas romanescas a partir da constituição de um herói não idealizado e que tem origens ou se vê forçado a frequentar o que Bakhtin (1983, p. 87-105), na sua apresentação da sátira menipeia, denomina de "submundo", designando o bas-fond, ou seja, cenários a que pertencem os estratos mais baixos da sociedade, a ralé. É o mundo da cozinha, dos mercados, dos bordéis, frequentados pelos escravos, pequenos comerciantes e trambiqueiros. Obviamente a presença de um personagem oriundo das camadas ditas populares não caracterizaria uma obra necessariamente como tal, outros elementos devendo contribuir para o diagnóstico, como sua autoria, o público a que se destinava, a forma de circulação ou elaboração de temas da cultura popular, fatores nem sempre facilmente verificáveis no que concerne à literatura antiga. ${ }^{4} \mathrm{Com}$ isso em mente, vou buscar uma primeira aproximação a esse universo através do exame do lugar que esses personagens ocupam na escala social, em vista, sobretudo, da exploração da força de trabalho, estendendo a análise a semelhanças estruturais entre as obras.

Que Esopo e Lúcio trabalhem, mesmo forçados a fazê-lo, já é um importante divisor de águas quando se considera os heróis dos romances de amor idealizado, membros de famílias abastadas, que passam seus dias entre o ginásio, os festivais religiosos e a casa do rétor - uma exceção é Dáfnis, jovem de origem nobre, mas abandonado na infância e adotado por escravos, que se ocupa do pastoreio até ser reintegrado ao núcleo familiar original. O panorama social dos romances gregos antigos não costuma ser muito variado. Em Quéreas e Calírroe (I d.C.) e Efesíacas (cerca II d.C.), considerados os primeiros exemplares preservados do gênero, os personagens se distribuem entre dois polos, o dos senhores e o dos escravos (com poucas exceções: piratas/bandoleiros, mercenários, e em muito menor número, pequenos prestadores de serviço, como estalajadeiras, pescadores, médicos). Segundo Scarcella (1977, p. 261):

A diferença entre as duas classes sociais é chocante e é dela que decorre uma insegurança pungente, concretizada em uma mobilidade econômica e social. O limite desse retrato é a precariedade da vida, por toda parte se percebe uma exibição de violência e morte, da parte dos que ameaçam a ordem existente (econômica e social, não constitucional) e dos que se esforçam por mantê-la.

o que faz com que muitos pensem que Fócio tenha confundido versões da mesma obra. No entanto, ele é incisivo em seu verbete, dando a entender ter lido ambos os livros: "Li as várias histórias das Metamorfoses de Lúcio de Patras. Seu estilo é claro, puro e repleto de doçura, evitando inovações na linguagem e cometendo excessos nas narrativas de cunho fantástico, de modo que se poderia dizer que é um segundo Luciano. Os dois primeiros livros são praticamente copiados de Lúcio ou o asno, de Luciano. Talvez tenha sido Luciano que o tenha copiado, pois quem é mais antigo, não é possível saber" (tradução própria). O texto supérstite é usualmente associado a Luciano, embora muitos estudiosos hoje contestem a autoria essencialmente por questões estilísticas, preferindo denominá-lo obra de Pseudo-Luciano, ou a considerem um epítome. Remeto a discussão a Mason (1999).

4 Para outros critérios a serem considerados na determinação do que seria literatura popular na Antiguidade, cf. Hansen (1998, XI-XII). No caso das obras em questão, o fato de terem autoria indefinida já aponta para a elaboração de tradições populares. G. Anderson (1976, p. 47-48) defende que Luciano, para ele o autor de Lúcio ou o asno, aproveita narrativas prévias, de caráter folclórico, sobre o asno - tive acesso apenas parcial à obra, por isso, não a cito nas referências. A se considerar o Romance de Esopo, isso é ainda mais evidente, uma vez que estratos narrativos presentes na obra podem ser rastreados desde o século V a.C., sendo provável que tenham circulado também na tradição oral, como bem argumenta Kurke (2011). 
Registra-se pontualmente, e como parte das peripécias experimentadas pelos heróis, a passagem de um desses polos ao outro, indo de senhores a escravos e vice-versa. Quéreas, por exemplo, ao ter sua trirreme incendiada e ser capturado pelas tropas persas que patrulhavam a região de Mileto, é vendido como escravo para Mitrídates, sátrapa da Cária, e destinado aos trabalhos forçados da lavoura (Q\&C, III. 7; IV. 2). ${ }^{5}$ Porém, assim que o sátrapa descobre sua identidade, passa a conceder-lhe outro tratamento, na esperança de usá-lo como meio para se aproximar de Calírroe, esposa de Quéreas, por quem se apaixonara. A condição dele é ambígua, pois embora tratado como livre, legalmente continua escravo. Mais adiante, levado a Babilônia por Mitrídates como sua testemunha num processo de tentativa de sedução, Quéreas reconquista efetivamente seu status de homem livre, já que o sátrapa, absolvido, deixa a cidade e seu "escravo" para trás e volta para Cária.

No período em que fica por sua conta na Babilônia, nada é dito sobre como Quéreas e seu fiel amigo Policarmo fizeram para garantir a subsistência. Essa simplesmente não é uma questão que interesse a Cáriton. E quando, mais tarde, eles se alistam no exército do faraó, não o fazem motivados pelo soldo, sobre o qual não há qualquer menção, mas pelo desejo de vingança e glória, um valor aristocrático afinal (Q\&C, VII. 1-2). Trabalhar para viver não é da índole de Quéreas, que, mesmo quando escravo, não conseguia cumprir sua cota diária de serviço, sendo coberto por Policarmo, que trabalhava pelos dois. Sendo assim, embora exista certa mobilidade social no mundo retratado por Cáriton, ela opera apenas nos extremos da escala social, e exclusivamente do senhor ao escravo e de volta, e é transitória, prestando-se antes a ilustrar os reveses da Fortuna do que a propor um retrato da realidade social.

Em Efesíacas, enquanto busca reencontrar sua esposa, vendida como escrava no estrangeiro, Habrocomes desempenha uma série de funções para sobreviver: ingressa na marginalidade aderindo a um bando de salteadores (Efes., II. 14), é vendido como escravo doméstico no Egito (Efes., III. 12), exerce o ofício de pescador na Sicília (Efes., V. 2), trabalha em uma pedreira na Itália (Efes., V. 8), uma das ocupações mais duras, menos valorizadas socialmente, cujo exercício cabia majoritariamente aos escravos. Abatido, resolve voltar à sua terra natal. Em uma escala em Rodes, reencontra sua mulher e retorna a Éfeso e à sua condição social original.

Como nota Scarcella (1977), há poucas opções de trabalho, sobretudo legal, para os homens livres que, por vicissitudes do destino, precisam encontrar um meio de subsistência, especialmente quando não podem recorrer a uma rede de solidariedade. Nas palavras do autor:

Parece que os personagens de Efesíacas, para viver confortavelmente, devem inventar uma ocupação que esteja às margens ou fora da lei, na medida em que eles não dispõem de um patrimônio familiar. Todos que trabalham (ou melhor, que vendem seu trabalho na condição de trabalhadores dependentes) encontram dificuldade para sobreviver (SCARCELLA, 1977, p. 253).

5 Há nesse episódio menção a uma rara situação de enfrentamento explícito entre senhores e escravos. Os companheiros de servidão de Quéreas, submetidos a condições desumanas de trabalho e alojamento, revoltam-se, quebram as correntes, degolam o capataz e fogem durante a noite ( $Q \& C$, IV. 2). Capturados, são atados ao tronco e, depois, sentenciados à morte na cruz, para dar exemplo aos outros prisioneiros. 
Sua conclusão é a de que "o trabalho não compensa" (SCARCELLA, 1977, p. 254) e que "o trabalhador é miserável e desprezado", a qual, não tenho dúvidas, Habrocomes subscreveria. Claro que o romance nos apresenta apenas um retrato parcial das condições de trabalho reservadas aos homens livres. Nada é dito sobre comerciantes, artesãos (nem todo fabrico, sobretudo ao que respeita a ourivesaria e artigos de luxo, estava a cargo dos escravos), retores, nem sobre as formas mistas de exploração das propriedades rurais, mas é inegável que Xenofonte aborda a difícil condição de subsistência do homem livre e expropriado em seu romance, ressaltando o enorme abismo que havia entre a classe mais abastada dos proprietários (de terras, de escravos, etc.) e dos despossuídos, pressionados, enquanto força de trabalho, pela existência desse enorme excedente de mão-de-obra escrava (muitas vezes, antes homens livres).

No romance cômico-realista inverte-se a situação. O trabalho faz parte da natureza do herói. Concedo que os protagonistas dos romances que examinarei estão inicialmente em polos opostos na escala social. Esopo, em o Romance de Esopo, é o contraponto completo aos heróis do romance de amor, pois nasce escravo e, como tal, é destinado à lavoura, a mais árdua das ocupações, antes de tornar-se criado doméstico. É verdade que alcança a liberdade, graças à maestria da palavra, ascendendo socialmente e passando a frequentar outros círculos sociais, mas estará sempre marcado pela sua origem, como bem comprova sua morte em Delfos. Por sua condição, tem o trabalho entranhado em si, como uma segunda natureza, e ainda tem consciência da exploração, como deixa claro no seguinte desabafo (RE 13):

"Como a escravidão é uma herança maldita e, mais que isso, detestada pelos deuses! Esopo, ponha a mesa! Esopo, aqueça o banho! Esopo, vá buscar água! Esopo, dê comida aos animais! Tudo quanto é penoso, cansativo, cheio de sofrimento ou servil a Esopo ordena-se que faça".

Já Lúcio, em Lúcio ou o asno, é membro de uma família bem-posta de negociantes da Acaia, cujos interesses representa em uma viagem de negócios ao norte da Grécia, em que se faz acompanhar por um escravo ( $L o A$ 1). Em sua viagem, confraterniza com a elite local, como é o caso de Hiparco, e conta com o favor do governador da província, que era relacionado à sua família, para ser repatriado, quando da reversão da metamorfose ( $L o A$ 55). Além disso, tem uma educação formal, pois declara-se autor de histórias e seu irmão, poeta elegíaco ( $L O A 55)$. Assim, é óbvio que Lúcio está mais próximo dos heróis do romance idealizado do que de Esopo ou mesmo de Encólpio, do Satíricon, este totalmente desprovido de uma rede de solidariedade familiar - note-se, no entanto, que ambos apresentam qualidades intelectuais, Esopo tendo sido dotado de eloquência por intervenção da deusa Ísis e das Musas, Encólpio tendo recebido treino retórico de Agamenão. A trajetória de Lúcio, no entanto, sofre uma reviravolta quando, por artes da magia, é transformado em asno, devendo passar por um período de provações que envolve trabalho extenuante e violência física antes de reconquistar sua condição anterior. Vale anotar que esse rebaixamento é muito mais duradouro e radical do que os sofridos por Quéreas e Habrocomes.

A transformação de Lúcio o aproxima de Esopo. Enquanto escravo e animal de carga, a experiência dos personagens não é muito diferente. Um, o escravo, desprovido de sua humanidade, é reduzido à animalidade, uma vez que dele só importa a força de trabalho; 
o outro, o asno, embora tenha preservado consciência e inteligência humanas, está privado da fala e submetido às tarefas mais penosas. Nenhuma ingerência têm sobre suas vidas, que pertencem a outrem, podendo ser negociados e, até mesmo, mortos se assim desejarem seus senhores. Escravo e animal de carga são equivalentes e intercambiáveis, como atesta a primeira venda de Esopo ao negociante de escravos Ofelião, cujo propósito era alugar animais de carga para aliviar suas peças $(R E 12)$ e, sem conseguir, ordena aos escravos que transportem no lombo a bagagem na viagem que farão até o litoral ( $R E 17)$, devendo desempenhar função que caberia às bestas. Na ocasião, Esopo, que por sua aparência grotesca é frequentemente comparado a animais e coisas, ${ }^{6}$ se encarrega de levar o fardo mais pesado, o cesto de pães que alimentará toda a tropa (RE 18). Em Lúcio ou o asno, ao ser destinado à roda do moinho, o burro anota: "Aí chegados, introduz-me no moinho, onde deparo com uma grande quantidade de bestas, companheiras de escravidão. [...] Naquele dia, atendendo a que o escravo vinha de fora, que já carregara com um fardo pesadíssimo e acabava de chegar duma jornada difícil, deixaram-me a descansar lá dentro" (LoA 42, itálicos meus). E mais adiante (LUCIANO, LoA 42):

"[...] em grande número, os [trabalhadores] do moinho pegam em cacetes, põem-se de volta de mim e, mal me precato (pois não via nada), zurzem-me valentemente, todos à uma, de modo que, tanta era a porrada, pus-me imediatamente a girar como um pião: é que a experiência tinha-me ensinado que, no cumprimento do dever, o escravo não deve esperar pela mão do senhor".

Tais aproximações ficam ainda mais evidenciadas em outros episódios dos romances. De fato, os enredos traçam paralelos notáveis na trajetória desses dois personagens, o que reforça a percepção de que para o público antigo havia uma equivalência entre o escravo e a besta de carga, associando-os ao que há de mais baixo. Essa consideração só se faz possível na medida em que se tenha em mente a transformação de Lúcio, que apesar de assumir aspecto animal, preserva características de homem, como deixa claro a seguinte passagem: "Ora eu, que, em tudo o mais, era um burro, continuava, no entanto, e no tocante a sentimentos e inteligência, a ser aquele mesmo homem, Lúcio... excepto na fala" (LUCIANO, LoA 15).

E é dessa perspectiva humana que experimenta sua nova condição, sofrendo então duplo rebaixamento: de homem à besta e de membro da elite à serviçal. Ao se perguntar por que, entre tantas possibilidades, Lúcio é transformado em asno, Brandão (2011, p. 67) sugere que, uma vez que no imaginário grego o animal está associado ao trabalho:

A intenção de Apuleio e Luciano poderia ser explorar justamente isso, fazendo com que um homem instruído - no desfecho da versão de Luciano ele se apresenta ao governador da província como "escritor de histórias e outras coisas" - e, portanto, livre de atividades braçais, passe pela experiência de ter de submeter-se ao trabalho.

6 A título de exemplo: "É o bulbo de um junco ou um homem? Se ele não pudesse falar, eu acharia que é um caldeirão com pés, uma marmita ou um ovo de gansa!" (RE 14); "Não é por acaso um tumor com dentes?" (RE 24); "É um sapo, um javali desembestado ou um jarro com calombo? O capitão de uma tropa de macacos, um frasquinho sem tirar nem pôr, o baú de um cozinheiro, ou um cachorro enjaulado?" (RE 88). 
Dentre os inúmeros paralelos na trajetória desses dois heróis, destaco inicialmente a sequência de Esopo junto a Xanto em Samos (RE 20-90) e de Lúcio junto aos sacerdotes da deusa Síria (AoL 35-41), já que há vários pontos de contato como a situação em que foram postos à venda, características dos proprietários, castigos sofridos. Winkler (1985, p. 280) apontou similaridade entre alguns desses episódios, mas com $O$ asno de ouro, de Apuleio, em mente. A rigor, como o autor de Madaura reelaborou versão(ões) grega(s) do Asno, as relações que aponta valem também para Lúcio ou o asno. Assim, vou retomar algumas de suas observações e expandi-las. Também é importante ressaltar que os textos divergem quanto à escolha do foco narrativo, o que certamente impacta a forma de apresentação dos personagens. Enquanto o Romance de Esopo apresenta um narrador onisciente em terceira pessoa, Lúcio ou o asno é narrado em primeira pessoa por um narrador protagonista. $\mathrm{O}$ quadro abaixo deve orientar a análise: ${ }^{7}$

\begin{tabular}{|c|c|c|}
\hline Episódios paralelos & Romance de Esopo & Lúcio ou o Asno \\
\hline Venda & Em Samos (RE 20-27) & $\begin{array}{l}1^{\mathrm{a}} \text { venda, em Bereia, Macedônia ( } L O A \\
35)\end{array}$ \\
\hline Donos: impostores & Xanto, filósofo & Filebo, sacerdote (36) \\
\hline $\begin{array}{l}\text { Apresentação do novo-es- } \\
\text { cravo }\end{array}$ & $\begin{array}{l}\text { Na casa de Xanto, alvoroço } \\
\text { das criadas (RE 29-30) }\end{array}$ & $\begin{array}{l}\text { Entre os membros da seita de Filebo } \\
(36)\end{array}$ \\
\hline Dotes sexuais & $\begin{array}{l}\text { Esopo e a esposa de Xanto } \\
(R E 75)\end{array}$ & Lúcio e a rica senhora $(50-56)$ \\
\hline $\begin{array}{l}\text { Castigos físicos/ maus-tra- } \\
\text { tos }\end{array}$ & Por Xanto (RE 77) & $\begin{array}{l}\text { Pelos cultores da deusa (38) } \\
\text { Pelos moleiros (42) }\end{array}$ \\
\hline Transporte de carga & & Estátua da deusa (37) \\
\hline Risco de morte & $\begin{array}{l}\text { Delfos (RE 140ss)* } \\
\text { [Esopo se atira do penhasco } \\
\text { e Lúcio, 33, pensa fazê-lo] }\end{array}$ & $\begin{array}{l}\text { Sacerdotes castigam o burro por ter-lhes } \\
\text { denunciado com seus zurros (38) }\end{array}$ \\
\hline insubordinação & $\begin{array}{l}\text { Contra Xanto ( } R E 29,36, \\
38,51) \text {; contra a esposa de } \\
\text { Xanto }(R E 44) \text {; contra estu- } \\
\text { dante }(R E 55)\end{array}$ & Contra os sacerdotes 38 \\
\hline Roubo da taça do templo & $\begin{array}{l}\text { Délfios simulam roubo da } \\
\text { taça do tesouro de Apolo por } \\
\text { Esopo }(R E 127-128)\end{array}$ & $\begin{array}{l}\text { Sacerdotes roubam taça do templo e es- } \\
\text { condem na bagagem de Lucio (41) }\end{array}$ \\
\hline Apresentações públicas & $R E 101,124$ & $\begin{array}{l}\text { Para os convidados do ricaço (48-49) } \\
\text { Para os convidados dos criados (50) } \\
\text { Nos jogos }(53)\end{array}$ \\
\hline
\end{tabular}

\section{O mercado e os compradores}

Escravo e alimária são vendidos e comprados (e, por vezes, roubados) sem cerimônia, passando de mão em mão várias vezes ao longo da narrativa, afinal, interessa apenas o seu valor de uso. Em Romance de Esopo, Esopo, que é propriedade de um senhor de terras, é vendido ainda no campo a um mercador de escravos, cuja intenção é promover um grande leilão em Éfeso. Após ter negociado quase todos os escravos nessa cidade, resta ao

7 As semelhanças não se esgotam nos episódios indicados, no entanto, optei por propor um recorte que permitisse uma análise mais centrada. Assim, certos vazios no quadro poderiam ser preenchidos por situações similares, mas pertencentes a outros momentos das obras e não aos trechos selecionados. 
mercador três peças: dois jovens e belos escravos, dotados de habilidades especiais (um músico e um gramático), e Esopo, extremamente feio e aparentemente boçal. O mercador vai tentar a sorte em Samos, onde os apregoa em praça pública. Inicialmente desprezado diante da beleza dos outros, Esopo termina comprado por Xanto, um filósofo avarento por uma quantia insignificante (RE 27):

Após elogiá-lo pela presteza da resposta, Xanto foi até o mercador e disse: "Por quanto vende esse aí?" [Mercador:] "Você quer que eu vire a piada do mercado?" [Xanto:] "Por quê?" [O mercador:] "Por ter deixado a esses, que são valiosos, e buscado esse outro, um escravinho digno de uma cusparada. Compre um daqueles e leve esse de brinde!" [Xanto:] "Ainda assim, quanto ele custa?" [Mercador:] "Eu o comprei por sessenta denários, gastei com ele quinze. Se empatar, está bom".

O valor é tão baixo que quando os coletores de taxas vêm conferir a venda, é o próprio Esopo que informa o valor, diante do embaraço de vendedor e comprador que, de fato, se tornam a chacota do mercado.

Lúcio, que anteriormente fora roubado por salteadores para transportar-lhes o produto do roubo e, depois, "alforriado" pela jovem senhora que fora sua companheira de cativeiro, é novamente surrupiado e vendido em condições similares a de Esopo:

"Os nossos condutores resolveram instalar-se nessa terra [Bereia, na Macedônia], pelo que puseram à venda as bestas, ou seja, nós. Um pregoeiro de falas lisonjeiras pôs-se no meio da praça a apregoar. E as pessoas aproximavam-se, abriam-nos a boca para inspeccionar, para ver, pela dentuça, a idade de cada um de nós; um adquiriu um animal, outro adquiriu outro... só eu fiquei até ao fim, pelo que o pregoeiro aconselhou [o dono] a levar-me de novo para casa: "Estás a ver" - disse ele -, "este foi o único que não encontrou comprador." [...] Sou vendido a este fulano pelo preço astronómico de trinta dracmas. ${ }^{8}$ E lá fui eu, gemendo, atrás do meu [novo] amo" (LUCIANO: LoA 35).

Devido às más condições em que estava em virtude dos maus-tratos que sofrera, antes e durante a fuga empreendida, foi o único animal a não ser arrematado. Por fim é adquirido por uma quantia irrisória.

As semelhanças começam com o fato de que ambos são oriundos do campo, onde já eram maltratados. Esopo era escravo de lavoura e, devido a sua constante rebeldia diante do capataz, que concebe até mesmo matá-lo para silenciá-lo ( $R E 11)$, é vendido e, durante sua jornada até o litoral, empregado para o transporte da bagagem. Lúcio, que deveria passar a vida despreocupadamente no campo como prêmio por ter auxiliado sua dona a escapar dos bandidos, é explorado pelos escravos como força para mover o moinho e transporte de carga. Aos excessos, reage e revida com coices os golpes que recebe, de modo que se cogita matá-lo ou castrá-lo ( $L o A 33)$. Fica claro, assim, como a revolta contra o tratamento injusto de que são objeto é um traço comum aos dois personagens, que pagam um preço alto por isso. No caso de Lúcio, quando se espalha a notícia da morte repentina da jovem senhora, os escravos da propriedade rural veem uma oportunidade para fugir, levando consigo tudo que pudessem carregar - os animais deveriam transportar o

8 Apesar da falta de parâmetros para definir o quanto valiam, de fato, 30 dracmas, o adjetivo "astronômico" é largamente interpretado como irônico, uma vez que o animal está malcuidado e é rejeitado pelos demais compradores. 
fruto do saque. Uma vez decididos a fixar-se em Bereia, vendem os animais, que já não têm para eles nenhuma serventia.

Também é notável paralelo entre os novos proprietários de Esopo e Lúcio, Xanto e Filebo, um, filósofo, outro, sacerdote da deusa Síria. ${ }^{9}$ Ambos atraem um séquito de admiradores, sejam discípulos, sejam adoradores da deusa. Embora Xanto, filósofo proeminente em Samos, não seja um charlatão, como o falso-sacerdote, sempre disposto a explorar a fé alheia, ambos são impostores, na medida em que não dominam as competências requeridas para a prática de seus ofícios ou não têm a compostura que eles exigem. Esopo desmascara Xanto em público diversas vezes, apontando sua impostura e fragilidades. Os defeitos de Filebo, contudo, são mais graves, pois com suas práticas religiosas encobre os verdadeiros propósitos de suas andanças: desfrutar dos amores dos jovens rapazes e cometer pequenos furtos, aproveitando-se da gente das aldeias. Lúcio é crítico dessas posturas, denunciando-o.

É notável também o paralelismo dos episódios em que se descreve a introdução dos novos escravos na morada de seus donos. As situações exploram a decepção causada pela chegada de um escravo que não cumpre as expectativas criadas. No caso de Esopo, a compra de um novo escravo fora pedido da esposa de Xanto, que queria ter a seu serviço um escravo de aparência impecável. Xanto introduz o novo criado assim (RE 29):

Xanto entrou e disse: "Senhora minha, acabaram-se as queixas e o bordão 'os meus escravos estão a seu serviço'. Veja, também eu comprei um espécime macho.” E a esposa de Xanto: "Graças, minha senhora Afrodite! Como é poderosa! São verídicas as visões que você envia durante o sono! Estava dormindo e subitamente tive um sonho em que você comprava e me presenteava com um escravo de formosura ímpar!" E Xanto: "Espere, senhora minha, e verá uma beleza jamais contemplada. Falo a verdade! Verá um Apolo, um Endímion, um Ganimedes!"’.

Não só a dona da casa fica alvoroçada, como atesta seu agradecimento a Afrodite, mas também a criadagem feminina, que sonha conseguir um marido de rara beleza. Quando se defrontam com Esopo à porta, as expectativas se desfazem ( $R E$ 30):

Uma delas foi e disse: "Onde está o meu senhor, o que acabou de ser comprado, o meu lindinho?” E Esopo respondeu: “Aqui!” E a escravinha disse: "Que Afrodite cubra de pancadas a sua cara feia! E por sua causa brigávamos, seu detrito?! Maldito seja! Entre aqui e não grude em mim. Fique bem longe!".

Com Lúcio, a cena não é muito diferente. Filebo anuncia a nova aquisição de forma ambígua, de modo a insinuar a seu séquito tratar-se de um rapaz, que poderia saciar seu o apetite sexual:

Mal chegámos ao local onde residia Filebo (tal era o nome do meu comprador) este bradou estridentemente da ombreira da porta: "Meniiinas! Acabo de comprar-vos um escravo, lindo, nédio e de raça capadócia." Ora essas "meninas", que [afinal] eram uma corja de panascas, colaboradores de Filebo, irromperam em aplausos, ao ouvirem este brado, pois cuidavam que se tratava realmente dum homem que ele tinha comprado. Quando, porém,

9 Dea Syria ou Atagartis é uma deusa da fertilidade cultuada na Hierópolis síria. Atribui-se a Luciano a redação de um tratado dedicado a essa divindade. 
constataram que o "escravo" era um burro, começaram a gozar com Filebo: “[Ó querida!], isto não é um escravo, mas sim um marido para ti própria. Aonde foste arranjá-lo? Oxalá tenhas uma sorte... para burro e dês à luz burricos chapados" (LUCIANO: LoA 35).

Ambas as cenas jogam ironicamente com o caráter erótico dos personagens, que tem um papel nos romances. Apesar da aparência repugnante, Esopo é dotado de um membro descomunal, mencionado inicialmente no referido episódio na resposta atravessada para a criada que o recepciona: "Você pensa que eu tenho o rabo atrás, mas o meu está aqui na frente!" (RE 30). Pelo mesmo motivo, é capaz de chamar a atenção da esposa do filósofo: "E ela, vendo o tamanho e a espessura de seu membro deixou-se conquistar e, esquecendo sua feiura, foi ferida pela paixão" ( $R E$ 75). Assim, a patroa, relevando sua deformidade, propõe dar a ele um manto, caso a satisfaça dez vezes consecutivas - ele falha na décima, mas isso nada depõe contra seu vigor sexual. Lúcio, por sua vez, antes mesmo da metamorfose, protagoniza longas cenas de amor com a criada de seu anfitrião em Himera, Palestra, e é em troca desses favores sexuais que tem acesso aos unguentos mágicos da dona da casa. Depois da transformação, seu atributo chama a atenção de uma rica senhora que paga a seu tratador para ter relações com o animal e, plenamente satisfeita com a performance do asno, decepciona-se quando Lúcio, de volta a sua forma humana, vai visitá-la, justificando-se:

"É que, por Zeus!, quem eu amava não era a tua pessoa, mas sim o burro que tu eras; com esse, e não contigo, é que eu dormia; cuidava que tu ainda tivesses conservado e trouxesses contigo pelo menos aquele singular e enorme símbolo do burro, mas, em vez disso, apareces-me aqui feito macaco, tu que eras aquele tão lindo e útil animal" (LUCIANO: LoA 56).

Os castigos físicos são parte da experiência servil, e tanto Esopo quanto Lúcio já haviam experimentado anteriormente à aquisição por seus novos amos, como está claro nos muitos os exemplos nos romances. ${ }^{10}$ No caso de Esopo, sua insolência e presteza para denunciar as falhas conceituais e a presunção do filósofo, custaram-lhe sua animosidade. Xanto exprime mais de uma vez o desejo de castigá-lo e arma ciladas para fazê-lo justificadamente ( $R E$ 42, mas também 50, 56, 61): "Hei de encontrar um pretexto pelo qual o açoitarei". As ameaças também são constantes: "Vou prender você e arrebentar de pancada!” (RE 58), "Esopo ficará em carne viva" (RE 61). Por fim, consegue o que quer graças a um acidente. Ao pedir que o escravo verificasse quantos pássaros estavam pousados à porta da casa (sendo que dois era sinal de sorte e um, indício de mau-agouro), Esopo afirma ter avistado um par, mas quando o filósofo sai de casa havia apenas uma, a outra ave tendo voado. Descontente, Xanto ordena: "Dispam-no! Tragam os chicotes!" Ele foi diligentemente surrado" ( $R E$ 77). Em outra ocasião, é amarrado e trancafiado ( $R E$ 80).

No episódio da deusa Síria, Lúcio também é severamente abusado após “denunciar" as práticas amorosas de seus proprietários, atraindo com seus zurros camponeses para a casa onde os sacerdotes se entregavam às orgias. Uma vez conhecida na aldeia sua licenciosidade, eles foram obrigados a fugir, culpando o burro por seu revés. Depois de cobrirem-no de impropérios, passaram à punição e só não o mataram porque não teriam forma de transportar a estátua da deusa (LUCIANO: AoL 38):

10 Cf. Romance de Esopo 9, 77, 107, 28, 140; Lúcio ou o asno 16, 18, 22, 24, 18, 28, 30, 31, 32, 33, 38, 42. 
“[...] tiraram a deusa de cima de mim, colocaram-na no chão e retiraram-me toda a colchoaria; depois amarraram-me, já em pelo, a uma árvore enorme; em seguida, deram em zurzir-me com o tal chicote feito de ossinhos, que por pouco não me mataram, ao mesmo tempo que me ordenavam que, daí para o futuro, me limitasse a ser um mudo transportador da deusa".

Essa última sequência também dialoga de perto com o episódio dos figos, que abre o Romance de Esopo (RE 2-3). Nele, Esopo, ainda privado da capacidade de falar, mas dono de uma inteligência ímpar, é acusado falsamente por dois outros escravos de ter comido os figos reservados para seu patrão, que eles haviam devorado. Diante da ameaça do castigo, Esopo denuncia seus companheiros provando, através do vômito provocado, não ter ingerido a fruta. $O$ patrão exige que os acusadores façam o mesmo e a verdade vem à tona, de modo que foram punidos. Lúcio é privado da linguagem articulada no momento da metamorfose, mas ainda assim consegue revelar os comportamentos errados que observa através de seus ornejos - na passagem examinada, a intenção de Lúcio era de imprecar aos deuses por lhe terem reservado servir a tal corja, mas as palavras se transmutam em um zurro enorme que atrai vizinhos.

\section{A taça roubada}

Há ainda outro tema que aproxima os heróis destes romances: o da taça roubada ao templo de um deus. Como observa Zimmermann (2007), na análise que dedica ao tópico, trata-se de parte de um motivo mais amplo, presente na narrativa popular: a imputação de roubo contra um inocente (cf. k 2118, Innocent person slandered as thief, no Motiv-index of Folk-literature, de Stith Thompson).

Conforme visto no comentário ao episódio dos figos, esse motivo está bem representado no Romance de Esopo. Ali também o escravo foi caluniado por seus companheiros de servidão, sendo posteriormente inocentado. Posteriormente, na sessão babilônica do romance (RE 101-123), Esopo, à serviço do rei Licurgo, é acusado falsamente por seu filho adotivo de tramar contra o monarca e sentenciado à morte - um guarda palaciano se apieda e o esconde na prisão para não ter de executar a sentença (RE 104). Na terceira vez em que a situação se repete, o herói não tem a mesma sorte. Em uma visita a Delfos, Esopo insultou a população local por sentir-se desprezado pelos délfios. Em retaliação, os governantes decidiram castigá-lo, tramando contra ele ( $R E$ 127):

"Planejaram então matá-lo por meio de um ardil [...]. Como não dispunham de um pretexto crível, maquinaram algo vil, a fim de que os peregrinos não pudessem socorrê-lo. Depois de terem espionado seu escravo, que pegara no sono junto à porta da cidade e levava com ele a bagagem, esconderam ali uma taça de ouro, antes retirada do templo. Sem saber da tramoia em curso, Esopo seguiu o caminho para a Fócida".

Os moradores perseguiram-no e acusaram-no de roubo. Embora alegasse inocência, a taça é encontrada entre seus pertences e ele é aprisionado e condenado à morte. Sem conseguir reverter a sentença, e arrastado pelos délfios para a beira do penhasco, de onde seria lançado, Esopo antecipa-se e se joga no abismo, maldizendo seus 
algozes (RE 142). ${ }^{11} \mathrm{O}$ narrador do romance deixa claro que Esopo é vítima de uma cilada, tendo morrido inocente. Zimmermann (2007, p. 282) aponta corretamente a correlação do episódio com os rituais expiatórios na Antiguidade, em que alguém era escolhido para purgar os erros de toda a comunidade, sendo exemplarmente castigado, independentemente de sua culpa objetiva.

Em Lúcio ou o asno encontra-se o mesmo motivo, mas com uma significativa alteração. Os sacerdotes da deusa chegam a um povoado onde são bem recebidos, obtendo a permissão de guardar a sua estátua no templo local. Vejamos (LUCIANO: LoA 41):

"Sucedeu, porém, que aqueles grandes ímpios, aquando da sua entrada no referido templo, roubaram uma taça sagrada, em ouro, que levaram escondida na [roupagem da] deusa. Ora os aldeões, ao darem pela coisa, puseram-se imediatamente em sua perseguição. Logo que os alcançaram, desceram dos cavalos, interrompem-lhes a marcha e começam a chamar-lhes ímpios e sacrílegos; depois revistaram tudo, até que deram com a taça no seio da deusa. Em vista disso, amarraram os maricas, trouxeram-nos pelo mesmo caminho e pregaram com eles na prisão; quanto à deusa que eu transportava, carregaram com ela e entregaram-na a um outro templo; e quanto ao objeto de ouro, devolveram-no à deusa padroeira da cidade".

A diferença do que se vê em Romance de Esopo, o narrador de Lúcio ou o asno, i. e, o asno, afirma que os sacerdotes roubaram mesmo a taça e a esconderam nas vestes da deusa. ${ }^{12}$ Para Zimmermann (2007, p. 288-289), trata-se de uma alteração intencional que ela atribui ao desejo de Luciano, um notório crítico da superstição e dos falsos profetas, de censurar os charlatões. ${ }^{13}$ Creio que faltou-lhe observar que, em contraste com o Romance de Esopo, Lúcio ou o asno é narrado em primeira pessoa, assumindo a perspectiva de seu protagonista. Esse narrador incrimina os sacerdotes - também os responsáveis pelo roubo da taça no Romance de Esopo, pois são eles que, para caluniar o fabulista, subtraem o objeto do templo do deus - mas Lúcio, assim como Esopo, é inocente do roubo. À sua revelia, o objeto furtado é escondido na bagagem que transporta e, uma vez descoberto, será penalizado - aprisionados seus proprietários, será arrestado e posto à venda. Visto por esse ângulo, há mais semelhanças do que diferenças entre os episódios considerados.

11 Estou citando o Romance de Esopo a partir da recensão G, tida por mais antiga e completa. A recensão W traz um desfecho diferente em que os délfios arremessam Esopo do precipício, dando cumprimento à sentença espúria. Sobre a transmissão do Romance de Esopo, cf. A. S. Duarte (ESOPO, 2017, p. 187-188).

12 O asno de ouro (IX, 9-10), de Apuleio, traz ainda uma outra variação dessa história. Nela os sacerdotes são perseguidos pelos moradores do povoado que encontram a taça de ouro escondida entre as roupas da estátua. Lúcio anota que “[...] mesmo em presença da prova de seu crime hediondo, os impudentes não se mostraram nem embaraçados, nem intimidados" (tradução de Ruth Guimarães), mas foram sarcásticos com seus acusadores. Embora ele não afirme que eram culpados, dada a péssima impressão que o narrador tem dos sacerdotes, fica sugerido que eles estavam implicados no roubo, mas, ao contrário de Lúcio ou o asno, não se declara peremptoriamente que eles eram os autores do roubo. Assim é possível especular que foram vítimas de uma armadilha como no caso de Esopo. Para análise da passagem, cf. Zimmermann (2007, p. 288-290).

13 Zimmermann (2007, p. 288): “It is remarkable that in the story as we find it in the 'Onos', it is explicitly mentioned that the priests themselves actually steal the gold goblet from the temple of the Mother of the Gods. This element makes the story of the 'Onos' diverge conspicuously from all known instances of the tale. I suggest that we see here a deliberate and meaningful contortion of the widely known stolen cup tale. [...] We may surely ascribe such a clever twist of the tale to Lucian, an author who in many of his works displays his dislike of pretenders such as these villainous and treacherous priests". 


\section{Conclusão}

Como pensar essas semelhanças estruturais entre as duas obras? No que respeita ao motivo do roubo da taça, que está vinculado à tradição esópica desde o séc. V a.C., pelo menos, quando é mencionado em uma passagem de Vespas (v. 1446-1448), de Aristófanes, não se deve cair na tentação fácil de pressupor que Lúcio ou o asno foi diretamente influenciado pelo romance esópico, cuja forma conhecida deve ter se consolidado quase que em paralelo à do texto luciânico, em II d.C.. Aliás, a considerar-se apenas esse motivo, ele está representado também na Bíblia, no Livro do Gênesis 44, em que José esconde sua taça na bagagem de um de seus irmãos e, depois, os captura e acusa de roubo para pô-los à prova. Então, me parece que sua presença, como as demais semelhanças estruturais apontadas, têm outra razão. E nesse ponto, retomo meu interesse inicial nessas obras, a sua origem nas narrativas populares de cunho oral.

Em Romance de Esopo já se verifica o uso de uma série de relatos de fontes diversas que, agregados ao núcleo duro da biografia do fabulista, transmitido por Heródoto (Histórias, II 134), dão corpo à narrativa. Além de episódios oriundos de A história de Ahikar, relato assírio que remonta ao séc. V a.C., anedotas associadas às vidas dos Sete Sábios, a epifania das musas em Teogonia e outras, contribuem para enriquecer a trajetória do personagem. ${ }^{14} \mathrm{Meu}$ ponto aqui é que o motivo da taça, embora fortemente associado à trajetória esópica, também tenha sua origem em narrativas populares, como outras que integram a obra.

O Asno também parece ter sido concebido a partir de relatos imemoriais, que circulavam na tradição oral. Em um passo de Cidade de Deus (XVIII, 18), Agostinho relata serem comuns na Itália histórias de feiticeiras disfarçadas de estalajadeiras que transformavam seus hóspedes em burros de carga. Tais metamorfoses estão presentes no mito grego e na poesia desde a Odisseia, em que se narra a mudança dos companheiros de Odisseu em porcos por Circe (Od. X, v. 239-240).

Revisando os pontos em comuns entre as obras analisadas à luz de sua própria natureza compósita e paródica, tendo a concordar com Winkler (1985, p. 285) que registram todo um repertório da narrativa popular, centrado em nos prazeres da mesa e da cama, no mundo do trabalho e da justiça e na percepção da fragilidade da vida. ${ }^{15}$

Defendo também que os protagonistas dessas obras representam um tipo de herói, cuja principal característica é a marginalidade e a superação das adversidades calcada na astúcia. Desprezados, seja por sua origem social ou aparência, tidos frequentemente como infra-humanos, são explorados, mas terminam por se impor graças à sua inteligência e aos mais diversos expedientes, sem ignorar a ajuda da Fortuna. Esse tipo de herói, que transita entre o trickster e o picaresco, cumpre uma trajetória definida, que se verifica nos paralelos que encontramos entre Esopo e Lúcio, que, afinal, são como duas faces de uma mesma moeda, representando perfeitamente o anti-herói no romance grego antigo.

14 Para maior detalhamento, cf. Duarte (2017, p. 190-196) e Kurke (2011).

15 Winkler (1985, p. 285): "Together, these six comparisons designate the common concern found in the AA (and the ass-talc) and Life of Aesop for food lost, slaves in peril, crimes and punishments, market values, lust and its disappointments, and elementary letter-play-the world of popular narrative". 
ANDERSON, Graham. Studies in Lucian's comic fiction. Leiden: Brill, 1976.

BAKHTIN, Mikhail. Particularidades do gênero, do enredo e da composição das obras de Dostoievski. In: se Universitária, 1983, 87-105. . Problemas da poética de Dostoievski. Rio de Janeiro: ForenBRANDÃO, Jacyntho L. Mente humana em corpo bestial. Aletria, [S. 1.], v. 21, n. 3, p. 63-73, dez. 2011.

DUARTE, Adriane da Silva. Apresentação ao Romance de Esopo. In: DUARTE, Adriane da Silva; MALTA, André. Fábulas seguidas de Romance de Esopo. São Paulo: Editora 34, 2017, p. 185-200.

ESOPO. Romance de Esopo. In: DUARTE, Adriane da Silva; MALTA, André. Fábulas seguidas de Romance de Esopo. São Paulo: Editora 34, 2017.

FERRARI, Franco (ed.). Romanzo di Esopo: introduzione e texto critico a cura de F. Ferrari. Milano: Rizzoli, 1997.

HANSEN, William (ed.). Anthology of Ancient Greek popular literature. Bloomington and Indianapolis: Indiana University Press, 1998.

KURKE, Leslie. Aesopic conversations: popular tradition, cultural dialogue and the invention of Greek prose. Princeton: Princeton University Press, 2011.

MASON, Hugh H. The Metamorphoses of Apuleius and its Greek sources. In: HOFMANN, Heinz (ed.). Latin fiction: the Latin novel in context. London: Routledge, 1999, p. 87-95.

REARDON, Bryan P. (ed.). Collected Ancient Greek novels. Berkeley: University of California Press, 2008, p. 125-75.

SAMÓSATA, Luciano de. Eu, Lúcio: memórias de um burro. In: . Luciano II. Coimbra: Imprensa da Universidade de Coimbra, 2012, p. 17-60.

SCARCELLA, Antonio M. Les structures socio-économiques du roman de Xénophon d'Éphèse. Revue des Études Grecques, v. 90, n. 430-431, jul./dez. 1977, p. 249-262. WINKLER, John J. The life of Aesop. In: . Auctor and actor: a narratological reading of Apuleius's Golden Ass. Los Angeles: University of California Press, 1985, p. 279-286.

ZIMMERMAN, Maaike. Aesop, the Onos, the Golden Ass, and a hidden treasure. In: PASCHALIS, Michael et al (eds.). The Greek and the Roman novel: parallel readings. Groningen: University of Groningen Press, 2007, p. 277-292.

Recebido em: 29/05/2020; Aceito em: 16/06/2020. 